\title{
Transport Function of Transcobalamin II
}

\author{
Mary E. Rappazzo and Charles A. Hall \\ From the Hematology Research Laboratory, Veterans Administration Hospital, \\ and the Department of Medicine, Albany Medical College of Union University, \\ Albany, New York 12208
}

A B S TRACT The uptake of free and bound ${ }^{57} \mathrm{CoB}_{12}$, principally to transcobalamin II (TC II), was studied in isolated, perfused liver and kidney of the dog. (1) There was good uptake of canine TC II-B ${ }_{12}$ by both organs. (2) In the liver TC II enhanced uptake over that of free B-12. (3) Renal uptake of free B-12 was greater

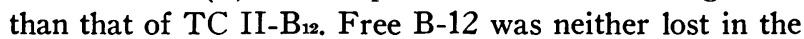
urine nor returned to the circulation. (4) On a per gram tissue basis, renal uptake of TC II-B $\mathrm{B}_{12}$ was greater than hepatic. (5) There was renal release or production of TC II (6) Some TC II but more of a larger molecular size binder came from the liver. (7) Passing free B-12 through the kidney enhanced its uptake by the liver. (8) Passing free B-12 through the liver depressed its uptake by the kidney. (9) It is postulated that the distribution of B-12 can be modified by $(a)$ different responses of tissue to TC II-B $\mathrm{B}_{12}$, $(b)$ synthesis of TC II by an organ, and $(c)$ the effects of B-12 passing through one organ to another.

\section{INTRODUCTION}

The plasma transport of vitamin $B_{12}(B-12)^{1}$ has been reviewed (1). Radioactive $B-12$ bound to one of the transport proteins, transcobalamin II (TC II), is cleared rapidly from plasma $(2,3)$, carries B-12 from the ileum to tissues $(2,4)$, and is necessary for life (5). This in vivo function is supported by the promotion by TC II of B-12 uptake by human cells in suspension $(4,6)$. The hepatic uptake of TC II-B $\mathrm{B}_{12}$ has been studied by external counting in man (4). Tan (7) showed murine TC II-B to be taken up by the liver and kidney of the mouse. Tissues vary widely in their B-12 content (8) and pos-

This work was presented in part to the Federation of American Societies for Experimental Biology, Chicago, Ill., 13 April 1971.

Received for publication 16 February 1972 and in revised form 1 May 1972.

${ }^{1}$ Abbreviations used in this paper: B-12, vitamin $\mathrm{B}_{12}$; IF, intrinsic factor; TC I, transcobalamin I; TC II, transcobalamin II. sibly distribution could be influenced by the reaction between TC II and its receptors in different tissues.

Transcobalamin I (TC I) is the dominant carrier of B-12 in plasma after it has been in the body for hours or days $(1,2)$. The need for two transport proteins has never been explained. Radioactive B-12 bound to TC I is cleared slowly from plasma $(2,3)$ and is not well taken up by cells in suspension $(4,6)$. Clinical experience demonstrates that B-12 can move from stores to other tissues but TC I seems to be an unlikely transport protein for this role. Transport between organs by TC II has not been studied.

The above questions were approached by injection of free B-12 and B-12 bound to canine transport proteins into isolated, perfused organs of the dog. This model was chosen because the dog has a B-12 transport protein chemically and functionally like that of human TC II (9). It was considered vital that the proteins and organs come from the same species.

\section{METHODS}

Isolated canine kidney and liver were perfused by a modification of the technique of Dodds which has been shown previously to sustain protein synthesis (10). The kidneys were removed and the blood washed out via a cannulated renal artery. Next the animal was exsanguinated; its red blood cells were used in the perfusion fluid. The portal vein was cannulated in situ, the liver flushed and removed with cannulas placed in the portal vein and the postcava. The right lateral lobe and the entire caudate lobe were isolated and only these segments perfused. Upon removal, both organs were immediately set in perfusion with a flow rate of approximately $0.4-0.5 \mathrm{ml} / \mathrm{g}$ per min. A pump pressure of 100 $\mathrm{mm} \mathrm{Hg}$ for the kidney and gravity pressure of $15-20 \mathrm{~cm}$ $\mathrm{H}_{2} \mathrm{O}$ above the liver were maintained. The perfusion fluid consisted of $30 \%$ canine erythrocytes which had been washed six times to remove all plasma proteins, $3.3 \%$ polyvinylpyrolidinone of mol wt 40,000 , and $0.38 \%$ trisodium citrate in Tyrode solution. The organs were perfused from $1-6 \mathrm{hr}$ and an evaluation of the system revealed a maintenance of perfusate $\mathrm{pH}$, oxygen consumption, and production of bicarbonate and carbon dioxide. The average osmolality of the perfusion fluid was $286 \mathrm{mOsm} / \mathrm{liter}$ with minimal hemolysis with time. All measured values were within the limits for maintaining proper organ function. 
The perfusate as described above was evaluated both for its ability to bind $\mathrm{B}-12$ and to promote uptake of ${ }^{57} \mathrm{CoB}_{12}$. $100 \mathrm{pg}$ of ${ }^{57} \mathrm{CoB}_{12}$ was added to $2 \mathrm{ml}$ perfusate; $4 \mathrm{pg}$ remained after dialysis. The total uptake of this $4 \mathrm{pg}$ by liver and kidney was about $2 \mathrm{pg}$. The relationship between hemoglobin found in the perfusate and its B-12 binding capacity was also determined. In no case was there enough hemolysate to bind a measurable amount of B-12. To further confirm that the perfusate did not contribute to the observations, a short experiment was run in which the Tyrode solution without red blood cells acted as the perfusion solution. The uptake of ${ }^{57} \mathrm{CoB}_{12}$ by the organs was similar to that when whole perfusate was used. Tyrode solution itself did not bind ${ }^{57} \mathrm{CoB}_{12}$.

${ }^{57} \mathrm{CoB}_{12}$ obtained from Philips-Duphar, Amsterdam, Holland, with specific activity of $202 \mu \mathrm{Ci} / \mu \mathrm{g}$ was used. The purity of the cyanocobalamin was verified by paper electrophoresis and assayed by Euglena gracilis for vitamin B-12. Gel filtration with Sephadex G-200 (Pharmacia Fine Chemicals, Inc., Piscataway, N. J.) as described for fractionation of plasma proteins (11) was used to study the B-12 binding proteins in organ output and for isolation of TC II from canine serum.

In those studies where dog serum was the source of TC II $100 \mathrm{pg}$ of ${ }^{57} \mathrm{CoB}_{12}$ was added per $2 \mathrm{ml}$ and of this $95-100 \%$ remained bound after dialysis. At no time was the binding capacity of serum exceeded (9), nor did any of the studies saturate the capacity of the organ for B-12. The erythrocyte binder used in three studies was prepared by repeated freezethawing of canine erythrocytes. It was, as identified by molecular size, an " $R$ " binder.

The basic experimental procedure consisted of injecting solutions of ${ }^{57} \mathrm{CoB}_{12}$ or ${ }^{57} \mathrm{CoB}_{12}$ bound to proteins into the organ circulation and measuring uptake of ${ }^{57} \mathrm{CoB}_{12}$. The injection time was $45 \mathrm{sec}$ and the material was injected directly into the cannula of the afferent vessel. Preliminary studies were done to determine organ uptake versus time. Of the labeled B-12 taken up by the organ, $95 \%$ or more was taken up in the first 2 min with only $1-2 \%$ or less taken up in subsequent samples collected over a period of $2 \mathrm{hr}$. Therefore $2 \mathrm{~min}$ was used as the basic collection period. B-12 uptake was usually calculated as the difference between input (injection) and $2 \mathrm{~min}$ output (collection). In a few studies the total organ was counted and its uptake of radioactivity calculated. Each day's perfusion was a study in itself and comparisons of uptake were made in the same organ under the same conditions.

Although we refer to uptake of TC II- $B_{12}$, only radioactivity was measured and the uptake of the intact complex was not proved. Finkler has shown that the HeLa cell takes up TC II- $B_{12}$ intact (12) and we have assumed such is the case here.

\section{RESULTS}

${ }^{57} \mathrm{CoB}_{12}$ and ${ }^{57} \mathrm{CoB}_{12}$ bound to canine serum, which is essentially all bound to TC II (9), were injected separately into the kidney and liver. Table $I$ is the average of 12 comparable experiments which shows that uptake of serum (TC II ) $-{ }^{57} \mathrm{CoB}_{12}$ by the liver was enhanced when compared to unbound ${ }^{57} \mathrm{CoB}_{12}$ while the uptake of unbound B-12 was greater in the kidney. The average uptake of free B-12 by the kidney was almost twice the uptake of serum (TC II) ${ }^{57} \mathrm{CoB}_{12}$. The reverse was true in hepatic uptake, i.e., serum (TC II) $-{ }^{57} \mathrm{CoB}_{12}$ uptake was about
TABLE I

Uptake of 100 pg Injection by Canine Kidney and Liver of ${ }^{57} \mathrm{CoB}_{12}$ and Serum (TC II) $-{ }^{57} \mathrm{CoB}_{12}$

\begin{tabular}{cccccc}
\hline & \multicolumn{2}{c}{ Kidney } & & \multicolumn{2}{c}{ Liver } \\
\cline { 2 - 3 } \cline { 5 - 6 } Uptake & $\begin{array}{c}\text { Free } \\
{ }^{57} \mathrm{CoB}_{12}\end{array}$ & $\begin{array}{c}\text { Serum } \\
{ }^{67} \mathrm{CoB}_{12}\end{array}$ & & $\begin{array}{c}\text { Free } \\
{ }^{57} \mathrm{CoB}_{12}\end{array}$ & $\begin{array}{c}\text { Serum } \\
{ }^{57} \mathrm{CoB}_{12}\end{array}$ \\
\hline $\begin{array}{c}\text { Per cent total } \\
\text { organ and SD }\end{array}$ & $82 \pm 8$ & $48 \pm 6$ & & $34 \pm 12$ & $67 \pm 15$ \\
$\begin{array}{c}\text { Avg pg/avg } \\
\text { g perfused }\end{array}$ & 3.6 & 1.9 & & 0.4 & 0.7 \\
\hline
\end{tabular}

twice that of free ${ }^{57} \mathrm{CoB}_{12}$. However, the amount of $\mathrm{B}-12$ taken up per gram of renal tissue was always greater than that taken up per gram of liver perfused. In four experiments canine serum was labeled in vivo or in vitro and fractionated by gel filtration (11). The TC II thus isolated and bound to either 31.6 or $100 \mathrm{pg}{ }^{57} \mathrm{CoB}_{12} / 2 \mathrm{ml}$, was injected for uptake studies and gave results similar to serum bound ${ }^{57} \mathrm{CoB}_{12}$. In the kidney a mean of $84 \%$ of the free ${ }^{57} \mathrm{CoB}_{12}$ was taken up as compared to $43 \%$ of that bound to isolated TC II. The liver took up $37 \%$ of the free and $58 \%$ of the TC II- ${ }^{57} \mathrm{CoB}_{12}$. The picogram per gram uptake values had the same relationship as in $\mathrm{Ta}$ ble I.

In three experiments, free ${ }^{57} \mathrm{CoB}_{12},{ }^{57} \mathrm{CoB}_{12}$ bound to B-12 binder in canine red blood cells, and serum (TC II)bound ${ }^{57} \mathrm{CoB}_{12}$ were introduced into the liver and kidney. The erythrocyte binder, which bound $30 \mathrm{pg}$ of the 100 $\mathrm{pg}$ added, seemed to have an inhibitory effect on renal uptake; it was half that of ${ }^{57} \mathrm{CoB}_{12}$ in serum. Uptake of the erythrocyte binder by the liver was equal to that of free ${ }^{57} \mathrm{CoB}_{12}$, but less than half that of ${ }^{57} \mathrm{CoB}_{12}$ in serum.

Preliminary analysis of the output of the kidney by gel filtration indicated that the ${ }^{57} \mathrm{CoB}_{12}$ existed bound to a substance with the elution volume of TC II. To evaluate this further, the liver was subjected to three sets of injections, Fig. 1. Serum (TC II) ${ }^{57} \mathrm{CoB}_{12}$ had an uptake of $67 \%$ (60 pg) and free ${ }^{57} \mathrm{CoB}_{12}$ of only $27 \%$ (27 pg). The final hepatic injection was the renal output collected for $2 \mathrm{~min}$ after injection of ${ }^{57} \mathrm{CoB}_{12}$. It contained $20 \mathrm{pg}{ }^{57} \mathrm{CoB}_{12}$ and produced an uptake of $67 \%(14 \mathrm{pg})$ in the liver, in agreement with the per cent uptake after the initial serum (TC II) $-B_{12}$ injection. On analysis of this renal output by gel filtration, the ${ }^{67} \mathrm{CoB}_{12}$ was bound exclusively to a protein of a molecular size corresponding to that of TC II $(1,11)$.

Additional studies were performed in which the perfusion fluid entering the liver flowed from the hepatic vein to the kidneys (Fig. 2). Of $100 \mathrm{pg}$ unbound ${ }^{57} \mathrm{CoB}_{12}$ injected into the liver, this organ took up only $14 \mathrm{pg}$ while the kidneys took up $10 \mathrm{pg}$ and $9 \mathrm{pg}$ from the liver output. When, in the same system, the $100 \mathrm{pg}{ }^{57} \mathrm{CoB}_{12}$ en- 


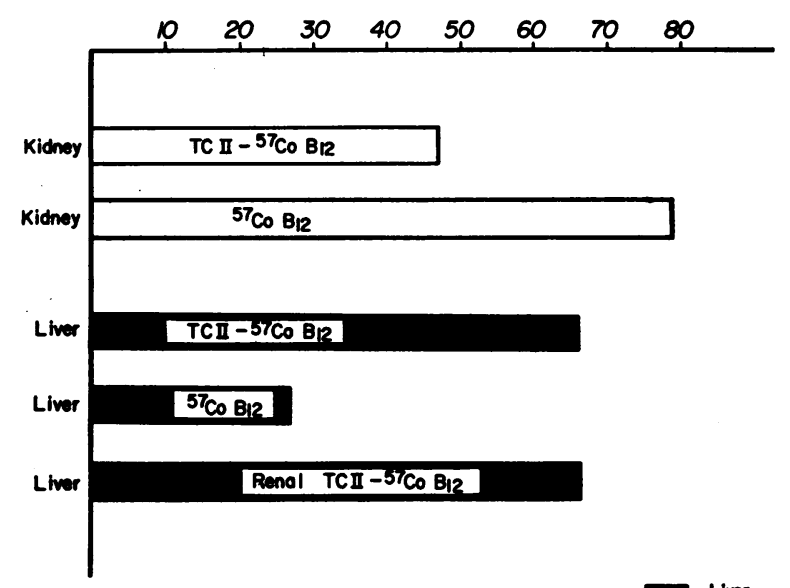

Figure 1 Per cent uptake of serum (TC II) $-{ }^{57} \mathrm{CoB}_{18}$ and ${ }^{57} \mathrm{CoB}_{12}$ by the kidney. Per cent uptake of serum (TC II)${ }^{57} \mathrm{CoB}_{12}$, ${ }^{57} \mathrm{CoB}_{12}$, and renal output (TC II) $-{ }^{57} \mathrm{CoB}_{12}$ by the liver.

tered the liver bound to TC II, hepatic uptake (42 pg) was definitely enhanced while the renal uptake, $8 \mathrm{pg}$ and $10 \mathrm{pg}$ of the hepatic perfusate, was not. These data reaffirmed the concept that TC II promoted uptake in the liver. Analysis of the liver output by Sephadex G-200 gel filtration showed ${ }^{57} \mathrm{CoB}_{12}$ bound predominately to a protein of a molecular size of $\pm 121,000$ and secondarily to a protein of $\pm 38,000$ molecular size. These correspond to the " $R$ " binders of B-12 and TC II, respectively $(1,11)$.

\section{DISCUSSION}

Enhancement of B-12 uptake by TC II in isolated organs in a homologous system has been shown for the first time. The fact that the erythrocyte binder did not promote B-12 uptake by either organ showed that the simple presence of a binding protein was not enough. Possibly some

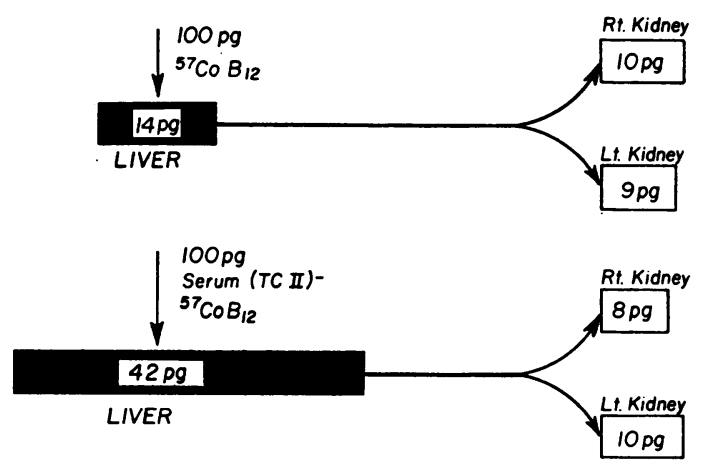

Figure 2 Uptake of ${ }^{57} \mathrm{CoB}_{12}$ and serum (TC II) $-{ }^{87} \mathrm{CoB}_{12}$ by the liver with flow of hepatic output to the kidneys. Renal uptake is given as picograms of B-12 extracted from perfusate coming from the liver. binders other than TC II would be effective but only TC II and the erythrocyte " $R$ " were tested. The increased uptake of TC II-B $\mathrm{B}_{12}$ over that of free B-12 by liver is in agreement with uptake by cells in culture (4, 6 ), but the high uptake of free B-12 by the kidney was unexpected. The free B-12 thus taken up was not excreted in the urine in a single study. Neither was it recirculated as determined by long-term monitoring of the perfusate and of the organ itself.

The TC II- $B_{12}$ uptake per gram was greater in the kidney although the difference could have been related more to conditions of flow, surface area exposed to TC II- $B_{12}$, etc. than to differences in reaction between TC II and its receptors. The possibility remains, however, that TC II exhibits tissue or organ selectivity in the distribution of B-12.

There was evidence that an organ receiving B-12 could modify its uptake by another organ. The binding of B-12 by TC II found in the kidney enhanced its uptake by the liver. The binding of $\mathrm{B}-12$ to an inactive protein from the liver depressed B-12 uptake by the kidneys. This kind of interrelationship between organs could have strong influence on distribution of the vitamin and the principles delineated may apply to transport of other substances as well.

Before the detection and study of B-12 transport proteins in plasma there were many attempts to show that intrinsic factor (IF) or a related substance functioned in the circulation as well as in the gut. The usual models were slices or homogenates of rat liver. There were some studies of serum-bound B-12 in these systems (13). Subsequently, Gullberg (14) showed that the component of a porcine IF preparation active in the rat liver homogenate system was an "R" binder and not IF. Since in none of the earlier work were the B-12 binding components of IF or serum separated, it cannot be determined which were the active principles. More recently Toporek, Gizis, and Meyer (15) studied human B-12 binders by perfusion of whole rat liver. The native B-12 binding proteins of the rat plasma were not removed from the perfusate and their presence may have influenced the findings. Moreover, there was little uptake of free B-12, which must have become bound to the rat TC II, by the rat liver. The liver of the mouse takes up B-12 bound to murine TC II (7), and this contradiction must be explained before the perfusion system can be adopted. Taken as a group these heterologous systems, for reasons that have not been identified, appear to be nonspecific. Rat liver systems have taken up B-12 bound to human serum (13), porcine IF preparation (13), non-IF binders in porcine IF preparation (14), an incompletely identified component of human serum (16), leukocyte " $R$ " binder (16), the " $R$ " binder in human gastric juice (16), the third binder in human serum (15), and human TC II (15). 
This lack of specificity is in sharp contrast to systems used to study intrinsic factor $(14,16)$ and the plasma B-12 binders in vitro $(4,6)$.

Production of TC II by the kidney has not been shown before. Tan (7) studied TC II production postnephrectomy in the mouse and considered liver to be the only source. A recent report of synthesis posthepatectomy (17), however, supports the present findings. Since TC II is the only plasma binder of its molecular size $(1,11)$, identification by gel filtration is reasonable. The $\pm 120,000$ mol wt binder coming from the liver requires further identification since several B-12 binders in the body are of that size (1).

\section{ACKNOWLEDGMENTS}

This work was supported in part by National Institutes of Health Grant AM02808.

The authors wish to thank W. J. Dodds, D.V.M. for her excellent technical advice and assistance.

\section{REFERENCES}

1. Grasbeck, R. 1969. Intrinsic factor and the other vitamin B-12 transport proteins. In Progress in Hematology. Grune \& Stratton, Inc., New York. 233.

2. Hall, C. A., and A. E. Finkler. 1965. The dynamics of transcobalamin II. A vitamin B-12 binding substance in plasma. J. Lab. Clin. Med. 65: 459.

3. Gizis, E. J., S. N. Arkun, I. F. Miller, G. Choi, M. F. Dietrich, and L. M. Meyer. 1969. Plasma clearance of transcobalamin I- and transcobalamin II-bound $\mathrm{Co}^{57}$ vitamin B $\mathrm{B}_{12}$. J. Lab. Clin. Med. 74: 574.

4. Finkler, A. E., and C. A. Hall. 1967. Nature of the relationship between vitamin $B_{12}$ binding and cell uptake. Arch. Biochem. Biophys. 120: 79.

5. Hakami, N., P. E. Neiman, G. P. Canellos, and J. Lazerson. 1971. Neonatal megaloblastic anemia due to inherited transcobalamin II deficiency in two siblings. N. Engl. J. Med. 285: 1163.

6. Reteif, F., C. W. Gottlieb, and V. Herbert. 1967. Delivery of $\mathrm{Co}^{57} \mathrm{~B}_{12}$ to erythrocytes from $\alpha$ and $\beta$ globulin of normal, B-12 deficient, and chronic myeloid leukemia serum. Blood J. Hematol. 29 : 837.

7. Tan, C. H-M. 1967. Metabolism of transcobalamin II, a dissertation. University Microfilms, Ann Arbor, Mich.

8. Rappazzo, M. E., H. A. Salmi, and C. A. Hall. 1970. The content of vitamin B-12 in adult and fetal tissue. Brit. J. Haematol. 18: 425.

9. Rappazzo, M. E., and C. A. Hall. 1972. Cyanobalamin transport proteins in canine plasma. Am. J. Physiol. 222: 202.

10. Dodds, W. J. 1969. Storage, release and synthesis of coagulation factors in isolated perfused organs. $\mathrm{Am}$. J. Physiol. 217 : 879.

11. Hall, C. A., and A. E. Finkler. 1971. Isolation and evaluation of the various B-12 binding proteins in human plasma. In Methods in Enzymology: Vitamins and Coenzymes. D. B. McCormich and L. D. Wright, editors. Academic Press, Inc., New York, 18C: 108.

12. Finkler, A. E. 1972. Transfer of $B_{12}$ from TC II to TC $\mathrm{I}$ in tissue culture. Fed. Proc. $31:$ 723. (Abstr.)

13. Herbert, V., and T. Spaet. 1958. Distribution of "intrinsic factor" activity. Am. J. Physiol. 195: 194.

14. Gullberg, R. 1969. Effect of hog vitamin $B_{12}$ binders on the uptake of vitamin $\mathrm{B}_{12}$ by tissue homogenates. Scand. J. Clin. Lab. Invest. $24: 391$.

15. Toporek, M., E. J. Gizis, and L. M. Meyer. 1971. Effect of human serum $B_{12}$ binders on uptake of vitamin $B_{12}$ by isolated perfused rat liver. Proc. Soc. Exp. Biol. Med. 136: 1119.

16. Simons, K., G. Kvist, and M. Sauren-Lindfors. 1966. The effect of purified vitamin $\mathrm{B}_{12}$ binding proteins on the uptake of vitamin $\mathrm{B}_{12}$ in tissues. Ann. Med. Exp. Biol. Fenn. 44 : 361.

17. Sonneborn, D. W., G. Abouna, and G. Mendez-Picon. 1971. Transcobalamin II synthesis in totally hepatectomized dogs. Fed. Proc. 30: 240. (Abstr.) 